\title{
Hubungan antara kompetensi keahlian dan kesesuaian praktik kerja industri terhadap kesiapan memasuki dunia kerja
}

\author{
Winda Cahyani W. ${ }^{1}$, Tri Atmadji S. ${ }^{2}$, Heru Wahyu Herwanto ${ }^{3}$ \\ 1. Universitas Negeri Malang, Indonesia | wcahyaning94@gmail.com \\ 2. Universitas Negeri Malang, Indonesia | tri.atmadji.ft@um.ac.id \\ 3. Universitas Negeri Malang, Indonesia | heru_wh@um.ac.id
}

\begin{abstract}
Abstrak
Orientasi Sekolah Menengah Kejuruan (SMK) adalah menyiapkan siswa untuk memasuki dunia industri. Penyiapan ini dilakukan dengan pembelajaran di sekolah maupun di dunia kerja. Pembelajaran di dunia kerja ditujukan untuk mendekatkan kompetensi siswa dengan dunia kerja sehingga siswa akan siap untuk memasuki dunia kerja. Penelitian ini merupakan penilitian deskriptif kuantitatif yang sifatnya korelasional. Tujuan dari penelitian ini adalah: (1) Untuk mengetahui seberapa tinggi kompetensi keahlian, kesesuaian praktik kerja industri dan kesiapan memasuki dunia kerja pada peserta didik kelas XII program keahlian Teknik Listrik di SMK Kabupaten Sidoarjo. (2) Untuk mengetahui adakah hubungan yang signifikan antara kompetensi keahlian dengan kesiapan memasuki dunia kerja pada peserta didik kelas XII program keahlian Teknik Listrik di SMK Kabupaten Sidoarjo. (3) Untuk mengetahui adakah hubungan yang signifikan antara kesesuaian praktik kerja industri dengan kesiapan memasuki dunia kerja pada peserta didik kelas XII program keahlian Teknik Listrik di SMK Kabupaten Sidoarjo. (4) Untuk mengetahui adakah hubungan yang signifikan antara kompetensi keahlian dan kesesuaian praktik kerja industri terhadap kesiapan memasuki dunia kerja pada peserta didik kelas XII program keahlian Teknik Listrik di SMK Kabupaten Sidoarjo. Populasi dari penelitian ini adalah seluruh peserta didik kelas XII program keahlian Teknik Listrik di SMK Kabupaten Sidoarjo yang berjumlah 353 siswa. Hasil penelitian ini adalah (1) Terjadi hubungan yang signifikan antara kompetensi keahlian dengan kesiapan memasuki dunia kerja pada siswa kelas XII program keahlian Teknik Listrik di SMK Kabupaten Sidoarjo. (2) Terjadi hubungan yang signifikan antara kesesuaian praktik kerja industri dengan kesiapan memasuki dunia kerja pada siswa kelas XII program kahlian Teknik Listrik di SMK Kabupaten Sidoarjo. (3) Terjadi hubungan yang positif dan signifikan antara kompetensi keahlian dan kesesuaian praktik kerja industri terhadap kesiapan memasuki dunia kerja pada siswa kelas XII program keahlian Teknik Listrik di SMK Kabupaten Sidoarjo.
\end{abstract}

\section{Kata Kunci}

SMK, kompetensi keahlian, praktik kerja industri, kesiapan kerja.

TEKNO Vol. 27 Issue 2, p93-104 | Jurusan Teknik Elektro, Universitas Negeri Malang, Indonesia | September 2017 W. Cahyaning W., T. Atmaji S., H. Wahyu H. | Hubungan Antara Kompetensi Keahlian dan Kesesuaian Praktik Industri ... 


\section{TEKNO Jurnal Teknologi, Elektro, dan Kejuruan}

http://journal2.um.ac.id/index.php/tekno | ISSN 1693-8739

\section{Pendahuluan}

Menurut UU Sistem Pendidikan Nasional No 20 tahun 2003, pendidikan kejuruan merupakan pendidikan menengah yang mempersiapkan peserta didiknya untuk bekerja dalam bidang tertentu (pasal 15 UU SNP 20 tahun 2003). Sekolah Menengah Kejuruan (SMK) merupakan pendidikan yang berorientasi mempersiapkan peserta didiknya untuk memasuki dunia kerja dan mencetak lulusan yang produktif.

Keberadaan SMK dalam mempersiapkan tenaga kerja tingkat menengah yang sesuai dengan kebutuhan industri dinilai masih belum optimal. Belum semua lulusan SMK memenuhi kebutuhan lapangan kerja yang sesuai dengan kompetensi yang dibutuhkan. Badan Pusat Statistik (BPS) mencatat angka pengangguran bertambah 300.000 orang menjadi 7,4 juta orang per Februari 2015. Tingkat pengaguran pada jenjang pendidikan Sekolah Menengah Kejuruan (SMK) memiliki persentase 9,05\%, pada Sekolah Menengah Atas (SMA) memiliki persentase $8,17 \%$, lulusan Diploma memiliki persentase $7,49 \%$, lulusan Universitas memiliki presentase 5,34\%, Sekolah Menengah Pertama (SMP) memiliki persentase 7,14\%, dan Sekolah Dasar (SD) memiliki persentase sebesar 3,61\%.

Hal yang sama terjadi pada Februari 2016 terdapat 7,0 juta orang pengangguran atau tingkat pengangguran terbuka (TPT) sebesar 5,50 persen. Tingkat pengaguran pada jenjang pendidikan Sekolah Menengah Kejuruan (SMK) memiliki persentase 9,84\%, pada lulusan Diploma memiliki persentase $7,22 \%$, dan Sekolah Dasar (SD) memiliki persentase sebesar $3,44 \%$.

Berdasarkan data tersebut, lulusan SMK menempati persentase paling tinggi dalam tingkat pengangguran terbuka (TPT) sebesar 9,84 persen dari jumlah total pengangguran di Indonesia sebesar 7,0 juta orang sampai bulan Februari 2016. Sehingga dapat disimpulkan bahwa kondisi TPT pada bulan Februari 2016, TPT mengalami penurunan jika dibandingkan dengan TPT pada bulan Februari 2015, kecuali pada jenjang pendidikan SMK yang meningkat sebesar 0,79 persen. Akibatnya banyak lulusan SMK yang seharusnya sudah siap untuk memasuki dunia kerja masih menganggur.

Peserta didik akan mendapatkan pekerjaan yang sesuai dengan bidangnya jika peserta didik memiliki kompetensi keahlian yang sesuai dan dibutuhkan oleh industri. Kurikulum SMK mencetak lulusan SMK menjadi lulusan yang siap kerja. Untuk mewujudkan hal itu maka peserta didik diwajibkan melaksanakan Praktik Kerja Industri (PRAKERIN). Dalam Prakrin, peserta didik diberikan wawasan, pelatihan, serta pengalaman berdasarkan pendekatan pendidikan sistem ganda.

Dalam pelaksanaan Prakerin juga tidak luput dari permasalahan. Sesuai dengan wawancara yang telah dilakukan oleh peneliti dengan Ketua Jurusan Elektronika Industri di SMK Negeri Jabon yang menjelaskan bahwa, permasalahan yang ada dalam prakerin yaitu sulitnya untuk menjalin kerjasama dengan pihak industri, banyak perusahaan yang besar menolak MoU yang 


\section{TEKNO Jurnal Teknologi, Elektro, dan Kejuruan}

http://journal2.um.ac.id/index.php/tekno | ISSN 1693-8739

telah diajukan sehingga penyaluran siswa menjadi tidak optimal. Secara ringkas (Miswanto, 2007) mengemukakan bahwa hambatan utama pelaksanaan praktik kerja industri baik oleh SMK maupun industri adalah masalah kerjasama, belum ada MoU kerjasama yang berkesinambungan dengan industri dalam pelaksanaan praktik kerja industri.

Sesuai dengan hasil wawancara peneliti dengan siswa SMK Krian 1 yang mengungkapkan bahwa kendala yang dialami ketika pelaksanaan prakerin adalah materi pelajaran belum disampaikan di sekolah, tetapi di industri dituntut untuk mengerjakannya. Hal ini sejalan dengan yang dikemukakan oleh (Mangkunegara, 2003) yang menyatakan bahwa"... tidak adanya relevansi dengan tuntuan dunia kerja, sering mengakibatkan sukarnya lulusan dalam menghadapi tuntutan dari dunia kerja."

Berdasarkan observasi yang dilakukan oleh peneliti ditemukannya ketidaksesuaian antara kompetensi keahlian yang dimiliki dengan kompetensi riil yang dilaksanakan. Hal ini berarti kompetensi keahlian menjadi salah satu faktor yang mempengaruhi kesiapan memasuki dunia kerja. Sesuai dengan hasil penelitian yang dilakukan oleh Oktavia menyatakan bahwa "Kompetensi kejuruan memberikan kontribusi sebesar $22.98 \%$ terhadap kesiapan memasuki dunia kerja industri siswa kelas XII Program Teknik Komputer dan Jaringan SMKN 2 Padang Panjang" (Oktavia, M. dkk, 2014). Berdasarkan permasalahan diatas dapat disimpulkan bahwa apabila peserta didik memiliki kompetensi keahlian yang baik maka peserta didik akan siap untuk memasuki dunia kerja.

Dari uraian latar belakang masalah tersebut, maka penulis dalam penelitian ini mengambil judul "Hubungan Antara Kompetensi Keahlian dan Kesesuaian Praktik Kerja Industri Terhadap Kesiapan Memasuki Dunia Kerja Pada Siswa Kelas XII Program Keahlian Teknik Listrik di SMK Kabupaten Sidoarjo".

\section{Metode}

\section{A. Rancangan Penelitian}

Metode penelitian diartikan sebagai cara ilmiah untuk mendapatkan data dengan tujuan dan kegunaan tertentu (Sugiyono, 2013). Penelitian ini menggunakan pendekatan kuantitatif, dengan rancangan penelitiannya adalah deskriptif korelasional. Penelitian deskriptif bertujuan untuk memperoleh informasi yang berkenaan dengan fenomena yang diamati saat ini, sedangkan penelitian korelasional adalah penelitian yang digunakan untuk meneliti kemungkinan adanya hubungan antar variabel.

Dalam penelitian ini variabel-variabel yang terlibat yaitu kompetensi keahlian $\left(X_{1}\right)$ dan kesesuaian praktik kerja industri $\left(\mathrm{X}_{2}\right)$ sebagai variabel bebas dan kesiapan memasuki dunia kerja (Y) sebagai variabel terikat. Serta mengetahui hubungan antara: (1) Kompetensi keahlian dengan kesiapan memasuki dunia kerja; (2) Kesesuaian praktik kerja industri dengan kesiapan

TEKNO Vol. 27 Issue 2, p93-104 | Jurusan Teknik Elektro, Universitas Negeri Malang, Indonesia | September 2017

W. Cahyaning W., T. Atmaji S., H. Wahyu H. | Hubungan Antara Kompetensi Keahlian dan Kesesuaian Praktik Industri ... 


\section{TEKNO Jurnal Teknologi, Elektro, dan Kejuruan}

http://journal2.um.ac.id/index.php/tekno | ISSN 1693-8739

memasuki dunia kerja; (3) Kompetensi keahlian dan kesesuaian praktik kerja industri dengan kesiapan memasuki dunia kerja.

Dalam penelitian ini populasinya adalah seluruh siswa kelas XII pogram keahlian teknik listrik di SMK Kabupaten Sidoarjo. Alasan pemilihan siswa kelas XII adalah siswa kelas XII sudah mempelajari semua kompetensi keahlian dan sudah melaksanakan praktik kerja industri, sehingga dianggap memiliki pemahaman yang baik dalam bidang keahliannya dan memiliki wawasan dan kesiapan dalam dunia kerja.

Dalam penelitian ini untuk menentukan jumlah sampel menggunakan Nomogram Herry King, dengan jumlah maksimum 2000, peneliti mengambil satu kelas di SMK Negeri 3 Buduran Sidoarjo, satu kelas di SMK Muhammadiyah 2 Taman, sepuluh kelas di SMK 1 Krian, dan dua kelas di SMK YPM 1 Taman. Kemudian didapatkan jumlah sampel sebanyak 164 siswa.

Dari 164 siswa yang dijadikan responden tidak semua datanya akan dianalisis. Hanya 150 data dari 164 responden yang layak digunakan sebagai data untuk penelitian. Hal ini dikarenakan 14 data yang didapatkan merupakan data ekstrim, yang dapat mnyebabkan hasil dari penelitian tidak mendapatkan kesimpulan yang tepat.

\section{B. Instumen Penelitian}

Instrumen penelitian merupakan alat yang digunakan oleh penelitian dalam mengumpulkan data agar pekerjaannya lebih mudah dan hasilnya lebih baik (Arikunto, 2010). Dalam penelitian ini menggunakan 2 instrumen yaitu: (1) Dokumentasi; (2) Angket/kuisioner.

Kuisioner dalam penelitian ini menggunakan skala Likert yang dibagi kedalam empat interval. "Skala Likert berupa pertanyaan atau pernyataan yang jawabannya berbentuk skala persetujuan atau penolakan terhadap pertanyaan atau pernyataan" (Sukmadinata, 2013).

Berdasarkan kajian teori yang telah ada, maka disusun sebuah kisi-kisi instrumen yang nantinya dijadikan dasa untuk pmbuatan sebuah instrumen berupa kuisionr/angket. Dengan jumlah item soal sebanyak 44 soal. Angket dibagi kedalam dua bagian yaitu bagian $A$ dan bagian $B$. Dimana angket A digunakan untuk mengukur variabel kesesuaian paktik kerja industri dan angket $B$ digunakan untuk mengukur variabel kesiapan memasuki dunia kerja.

Dalam angket terdapat pernyataan positif dan negatif. Tidak semua item soal digunakan untuk mengambil data, karena pada item ketujuh pada bagian B tidak valid. Item yang tidak valid, tidak digunakan dalam penelitian. Karena tidak layak digunakan untuk mengukur suatu variabel.

\section{Pengujian Instrumen}

Sebelum penelitian dilakukan, peneliti melakukan suatu uji instrumen penelitian yaitu untuk mengetahui apakah instrumen tersebut telah memenuhi persyaratan atau belum. Dalam melakukan pengujian angket/kuisioner digunakan uji validitas dan uji reliabilitas. Uji validitas adalah suatu ukuran yang menunjukkan tingkat-tingkat kevalidan atau kesahihan suatu 


\section{TEKNO Jurnal Teknologi, Elektro, dan Kejuruan}

http://journal2.um.ac.id/index.php/tekno | ISSN 1693-8739

instrument (Arikunto, 2014). Suatu instrumen yang valid atau sahih mempunyai validitas yang tinggi. Sebuah instrumen dikatakan valid apabila mampu mengukur apa yang diinginkan. Item soal dikatakan valid apabila hasil $r_{\text {hitung }}$ memiliki nilai sama dengan atau lebih besar dari nilai $r_{\text {tabel }}\left(r_{\text {hitung }} \geq 1,524\right)$.

"Reliabilitas berkenaan dengan tingkat keajegan atau ketetapan hasil pengukuran. Suatu instrumen memiliki tingkat reliabilitas yang memadai, jika instrumen tersebut digunakan mengukur aspek yang diukur beberapa kali hasilnya tetap sama atau relatif sama" (Sukmadinata, 2013). Reliabilitas instrumen dianalisis menggunakan koefisien Alpha Cronbach. Ketentuan item soal dinyatakan reliabel jika tidak kurang dari $0,7(\alpha>0,7)$.

\section{Analisis Data}

Setelah data penelitian terkumpul, kemudian tahap selanjutnya adalah menganalisis data. Analisis data dalam penelitian ini menggunakan analisis deskriptif, dan uji analisis prasyarat. Analisis statistik deskriptif adalah statistik yang digunakan untuk menganalisis data dengan cara mendeskripsikan atau menggambarkan data yang telah terkumpul sebagaimana adanya tanpa bermaksud membuat kesimpulan yang berlaku untuk umum atau generalisasi. Analisis statistik deskriptif dalam penelitian ini digunakan untuk menggambarkan data dari masing-masing variabel agar lebih mudah dipahami. Sedangkan uji analisis prasyarat digunakan untuk menguji data sebelum dilakukan uji hipotesis. Uji analisis prasyarat diantaranya yaitu, uji normalitas, uji linieritas, uji multokolinieritas, uji heterokedasitas, uji autokorelasi dan uji heterokedasitas.

Hipotesis yang telah dirumuskan akan diuji dengan statistik parametris. Penggunaan statistik parametris mengisyaratkan bahwa data setiap variabel yang akan dianalisis harus berdistribusi normal. Oleh karena itu sebelum pengujian hipotesis dilakukan, maka terlebih dahulu akan dilakukan pengujian normalitas data. Pengujian normalitas dilakukan dengan uji Kolmogorov-Smirnov (K-S). Kriterianya jika nilai Asym Sig lebih dari 0,05 maka data berdistribusi normal.

Uji linieritas bertujuan untuk mengetahui apakah dua variabel yang akan dikenai prosedur analisis statistik korelasional menunjukkan hubungan yang linier atau tidak (Priyatno, 2012). Kriterianya adalah jika nilai signifikansi $<0,05$ artinya data linier. Uji multikolinieritas bertujuan untuk menguji apakah model regresi ditemukan adanya korelasi antar variabel bebas atau independen (Ghozali, 2011). Korelasi antar variabel bebas sebaiknya kecil. Semakin kecil korelasi antar variabel bebas semakin baik untuk model regresi yang digunakan.

Uji autokorelasi ini bertujuan untuk mengetahui adanya korelasi antara kesalahan pengganggu pada periode $t$ dengan kesalahan periode $t$ sebelumnya pada regresi linier yang digunakan. Uji hetokedasitas bertujuan untuk menguji apakah dalam model regresi terjadi ketidaksamaan varience dari residual satu pengamatan ke pengamatan yang lainnya (Ghozali, 2011).

TEKNO Vol. 27 Issue 2, p93-104 | Jurusan Teknik Elektro, Universitas Negeri Malang, Indonesia | September 2017

W. Cahyaning W., T. Atmaji S., H. Wahyu H. | Hubungan Antara Kompetensi Keahlian dan Kesesuaian Praktik Industri ... 


\section{TEKNO Jurnal Teknologi, Elektro, dan Kejuruan}

http://journal2.um.ac.id/index.php/tekno | ISSN 1693-8739

Uji hipotesis digunakan untuk menjawab rumusan masalah yang telah diajukan pada penelitian ini. Uji hipotesis yang digunakan pada penelitian ini adalah uji parsial dan uji regresi linier berganda. Uji parsial digunakan untuk menguji hipotesis pertama dan kedua, sedangkan hipotesis ketiga diuji dengan regresi linier berganda. Analisis parsial digunakan untuk mengetahui apakah secara parsial variabel independen berpengaruh secara signifikan atau tidak terhadap variabel dependen.

Analisis regresi linier berganda digunakan untuk menganalisis variabel bebas secara simultan dengan variabel terikat. Dalam penelitian ini meggunakan uji $\mathrm{F}$ untuk mengetahui apakah variabel independen berpengaruh signifikan terhadap variabel dependen. Dalam perhitungan analisis korelasi parsial dan regresi linier berganda menggunakan bantuan SPSS 20.0 .

\section{Hasil}

\section{A. Deskripsi Kondisi Kompetensi Keahlian}

Kompetensi keahlian pada siswa kelas XII program keahlian teknik listrik di SMK Kabupaten Sidoarjo, dari hasil uji analisis deskriptif memiliki rata-rata sebesar 84,15. Dilihat dari frekuensinya, 111 responden atau $74 \%$ masuk dalam kategori tinggi, sedangkan 39 responden atau $26 \%$ ada dalam kategori sangat tinggi. Jadi dapat disimpulkan 111 responden dengan persentase $74 \%$ memiliki tingkat kompetensi keahlian yang tinggi. Hal ini berarti bahwa secara umum dapat digambarkan kompetensi keahlian yang dimiliki siswa dinyatakan tinggi.

Tingginya kompetensi keahlian yang dimiliki oleh siswa dipengaruhi oleh beberapa aspek yaitu aspek kognitif, afektif dan psikomotorik. Dalam hal ini, kompetensi diartikan dengan pengetahuan, keterampilan dan kemampuan yang dikuasai oleh seseorang yang telah menjadi bagian dari dirinya, sehinga ia dapat melakukan perilaku kognitif, afektif, dan psikomtorik dengan sebaik mungkin. Sesuai dengan itu, Finch dan Crunkilton (Mulyasa, 2006) mengartikan kompetensi sebagai penguasaan terhadap suatu tugas, keterampilan, sikap dan apresiasi yang diperlukan untuk menunjang keberhasilan.

\section{B. Deskripsi Kondisi Kesesuaian Praktik Kerja Industri}

Kesesuaian prakerin pada siswa kelas XII program keahlian teknik listrik di SMK Kabupaten Sidoarjo, dari hasil uji analisis deskriptif data memiliki rata-rata sebesar 68,20 . Dilihat dari frekuensi tertinggi sebanyak 65 responden dengan persentase sebesar $43 \%$ masuk kedalam kategori sesuai. Kesesuaian praktik kerja industi dapat memberikan pengaruh berkembangnya kompetensi yang sudah dimiliki oleh siswa, memberikan gambaran konsep kerja nyata, disiplin kerja dan sikap kerja yang terstruktur. Dengan demikian kesesuaian prakerin juga akan menambah tumbuhnya motivasi kerja pada siswa. 


\section{TEKNO Jurnal Teknologi, Elektro, dan Kejuruan}

http://journal2.um.ac.id/index.php/tekno | ISSN 1693-8739

Menurut konsep Prakerin (Depdikbud, 1994) bahwa pelaksanaan Prakerin memiliki tujuan khusus yaitu: (a) mempersiapkan siswa untuk belajar bekerja mandiri dan secara tim; (b) meningkatkan status dan kepribadian para siswa sehingga mereka berinteraksi, berkomunikasi, dan memiliki rasa tanggung jawab serta disiplin yang tinggi; (c) memberikan kesempatan dan garansi bagi siswa yang berpotensi untuk menjadi tenaga kerja yang terampil berdasarkan pengakuan standar profesi yang ditentukan.

Berdasarkan tujuan tersebut, prakerin merupakan hal yang sangat penting. Prakerin memberikan kesempatan yang efektif kepada siswa untuk mengenal dunia kerja secara nyata.

\section{Deskripsi Kesiapan Memasuki Dunia Kerja}

Kesiapan memasuki dunia kerja pada siswa kelas XII program keahlian teknik listrik di SMK Kabupaten Sidoarjo, dari hasil uji analisis deskriptif data memiliki rata-rata sebesar 140, 08. Dilihat dari frekuensi tertinggi sebanyak 64 responden dengan persentase sebesar $43 \%$ masuk kedalam kategori tinggi. Tingginya kesiapan kerja dapat dipengaruhi oleh beberapa faktor, diantaranya yaitu kematangan fisik, psikologis, keterampilan dan pengalaman dari luar.

Sedangkan kesiapan memasuki dunia kerja adalah keadaan dimana siswa telah mencapai titik metangan fisik, mental serta memiliki kemampuan yang mumpuni untuk melakukan kegiatan tertentu. Dengan demikian siswa harus mampu mempersiapkan diri secara fisik maupun psikologis untuk mnerima dan melaksanakan tugasnya.

Unsur-unsur yang mempengaruhi kesiapan kerja mencakup tiga aspek, yaitu: (1) Kondisi fisik, mental dan emosional, (2) Kebutuhan-kebutuhan, motif dan tujuan, (3) Keterampilan, pengetahuan dan pengertian lain yang telah dipelajari (Slameto, 2010). Kesiapan dalam memasuki dunia kerja adalah hal yang utama. Dengan memiliki kesiapan siswa akan lebih mudah melaksanakan tugasnya dengan lancar dan mendapatkan hasil yang optimal.

\section{Hubungan antara Kompetensi Keahlian dan Kesiapan Memasuki Dunia Kerja pada Siswa Kelas XII Program Keahlian Teknik Listrik di SMK Kabupaten Sidoarjo.}

Berdasarkan hasil uji parsial pada SPSS 20.0, korelasi parsial antara $X_{1}$ dengan $Y$, diperoleh

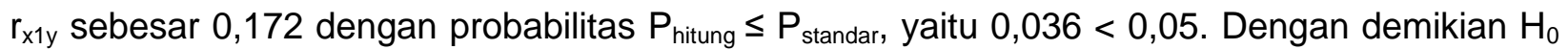
ditolak, artinya terjadi hubungan yang signifikan antara kompetensi keahlian dan kesiapan memasuki dunia kerja pada taraf signifikansi $5 \%$. Hal tersebut mengindikasikan bahwa setiap kenaikan atau penurunan kompetensi keahlian akan berpengaruh terhadap tingkat kesiapan memasuki dunia kerja. Dapat diartikan juga bahwa kompetensi keahlian merupakan faktor utama yang mempengaruhi tinggi rendahnya kesiapan memasuki dunia kerja. Hasil penelitian ini didukung oleh penelitian terdahulu yang dilakukan oleh Putriatama, Ega, dkk yang mengungkapkan bahwa, kompetensi kejuruan berpengaruh positif signifikan terhadap kesiapan kerja (Putriatama, Ega, dkk, 2016)

TEKNO Vol. 27 Issue 2, p93-104 | Jurusan Teknik Elektro, Universitas Negeri Malang, Indonesia | September 2017

W. Cahyaning W., T. Atmaji S., H. Wahyu H. | Hubungan Antara Kompetensi Keahlian dan Kesesuaian Praktik Industri ... 


\section{TEKNO Jurnal Teknologi, Elektro, dan Kejuruan}

http://journal2.um.ac.id/index.php/tekno | ISSN 1693-8739

Sekolah harus mampu menggunakan dunia kerja sebagai pijakan dalam perencanaan kurikulumnya, sehingga ada kaitannya dengan apa yang dipelajari di sekolah dengan apa yang dipelajari di dunia usaha/industri (Wena, 1997). Merujuk pernyataan diatas kompetensi keahlian merupakan hal yang sangat patut untuk diperhitungkan dalam mempersiapkan siswa memasuki dunia kerja. Kompetensi keahlian yang sesuai dengan apa yang dikerjakan di dunia industri oleh siswa akan memberikan keterampilan yang cukup sebagai bekal memasuki dunia kerja.

Dari hasil penelitian yang telah dilakukan dapat disimpulankan bahwa seorang peserta didik yang memiliki kompetensi yang memenuhi standart kualifikasi yang dibutuhkan oleh dunia usaha maupun dunia industri akan mudah dalam penyesuaian diri dengan organisasi tempat kerja. Keterampilan yang dilatihkan selama proses pembelajaran akan meningkatkan kesiapan peserta didik memasuki dunia kerja.

\section{E. Hubungan antara Kesesuaian Praktik Kerja Industri dan Kesiapan Memasuki Dunia Kerja pada Siswa Kelas XII Program Keahlian Teknik Listrik di SMK Kabupaten Sidoarjo.}

Berdasarkan hasil uji parsial pada SPSS 20.0 korelasi parsial antara $X_{1}$ dengan $Y$, diperoleh $r_{x 2 y}$ sebesar 0,455 dengan probabilitas $P_{\text {hitung }} \leq P_{\text {standar, yaitu }} 0,000 \leq 0,05$. Dengan demikian $H_{1}$ diterima, artinya ada hubungan yang signifikan antara kesesuaian prakerin dengan kesiapan memasuki dunia kerja pada taraf signifikansi $5 \%$. Hal ini berarti kesesuaian prakerin memiliki peranan yang sangat penting dalam mempengaruhi kesiapan dalam memasuki dunia kerja.

Praktik kerja industri adalah suatu bentuk penyelenggaraan pendidikan keahlian profesional yang memadukan secara sistmatis dan sinkron pendidikan program di sekolah dan program penguasaan keahlian yang diperoleh melalui kegiatan bekerja secara langsung di dunia kerja, terarah untuk mencapai satu tingkatan keahlian tertentu (Depdikbud, 1994).

Adanya prakerin mendukung berkembangnya keterampilan siswa dalam mengimplementasikan pengetahuan yang telah didapatkan selama di sekolah. Sehingga memberikan manfaat yang besar untuk siswa dalam memasuki dunia kerja. Oleh sebab itu semakin relevan prakerin yang dilaksanakan siswa, maka semakin siap siswa dalam menghadapi dunia industri. Hasil penelitian Wohlin dan Regnell diperoleh kesimpulan bahwa dengan adanya relevansi Prakerin diharapkan pendidikan kejuruan seperti SMK dapat mempersiapkan siswa agar siap dalam menghadapi perkembangan ilmu pengetahuan dan industri terkait bidang keahlian siswa (Wohlin, Claes dan Bjorn Regnell, 1999)

Dalam pelaksanaan prakerin siswa diharapkan mampu mengetahui pekerjaan-pekerjaan yang sesuai dengan dengan keahlian yang dimilikinya serta siswa lebih siap dalam menentukan pilihan pekerjaannya. Jadi dapat disimpulkan semakin tinggi tingkat kesesuaian prakerin siswa dengan kompetensi keahlian yang dimilikinya maka semakin tinggi pula kesiapan siswa dalam memasuki dunia kerja.

TEKNO Vol. 27 Issue 2, p93-104 | Jurusan Teknik Elektro, Universitas Negeri Malang, Indonesia | September 2017

W. Cahyaning W., T. Atmaji S., H. Wahyu H. | Hubungan Antara Kompetensi Keahlian dan Kesesuaian Praktik Industri ... 


\section{TEKNO Jurnal Teknologi, Elektro, dan Kejuruan}

http://journal2.um.ac.id/index.php/tekno | ISSN 1693-8739

\section{F. Hubungan antara Kompetensi Keahlian dan Kesesuaian Praktik Industri Secara Bersama-sama terhadap Kesiapan Memasuki Dunia Kerja pada Siswa Kelas XII Program Keahlian Teknik Listrik di SMK Kabupaten Sidoarjo.}

Berdasarkan hasil uji pada SPSS 20.0 menggunakan uji regresi linier berganda dapat diketahui bahwa hubungan antara kompetensi keahlian dan kesesuaian praktik kerja industri secara bersama-sama terhadap kesiapan memasuki dunia kerja memiliki hubungan yang positif dan signifikan. Berdasarkan tabel interpretasi menurut Sugiyono tingkat kekuatan hubungan masuk dalam kategori sedang, karena nilai korelasi $R$ berkisar antara 0,40 - 0,599 yaitu sebesar 0,486 (Sugiyono, 2013).

Nilai koefisien determinasi $X_{1}$ dan $X_{2}$ terhadap $Y\left(R^{2}{ }_{y 12}\right)$ sebesar 0,237 dan memiliki pengaruh yang signifikan dengan $F_{\text {hitung }}$ lebih besar dari $F_{\text {tabel }}$ yaitu 22,776 $>2,995$ pada taraf signifikansi $5 \%$. Mengingat hubungan antara kompetensi keahlian dan kesesuaian prakerin terhadap kesiapan memasuki dunia kerja memiliki tingkat korelasi yang sedang dan koefisien determinan sebesar 23,7\%, sehingga dimungkinkan bahwa kompetensi kahlian dan kesesuaian prakerin dapat dijadikan prediksi keadaan kesiapan memasuki dunia kerja. Model regresi linier berganda 2 vaiabel bebas adalah sebagai berikut:

$\mathrm{Y}=0,388 \mathrm{X}_{1}+0,638 \mathrm{X}_{2}$

Model regresi tersebut menunjukkan bahwa nilai koefisien regresi $X 1$ sebesar 0,388 yang berarti bahwa nilai kompetensi keahlian $\left(\mathrm{X}_{1}\right)$ meningkat satu satuan maka nilai kesiapan kerja $(\mathrm{Y})$ akan meningkat 0,388 satuan dengan asumsi $\mathrm{X}_{2}$ tetap, demikian juga dengan nilai koefisien Regresi $X_{2}$ sebesar 0,638 yang berarti jika nilai kesesuaian prakerin $\left(X_{2}\right)$ meningkat satu satuan, maka nilai kesiapan kerja $(Y)$ akan meningkat 0,638 satuan dnegan asumsi $X_{1}$ tetap.

Hubungan ini juga diperkuat dengan adanya perhitungan sumbangan relatif dan sumbangan efektif dari kedua variabel. Kompetensi keahlian memberikan sumbangan relatif sebesar $12,45 \%$, sedangkan kesesuaian prakerin memberikan sumbangan relatif sebesar $87,55 \%$. Sumbangan efektif dari prediktor kompetensi keahlian sebesar $69,93 \%$ dan sumbangan efektif kesesuaian prakerin sebesar $4,92 \%$. Total sumbangan efektif kedua prediktor adalah $74,85 \%$. Ini berarti bahwa kesiapan memasuki dunia kerja siswa dapat dijelaskan oleh kompetensi keahlian dan kesesuaian praktik kerja industri sebesar $74,85 \%$, sedangkan sisanya dipengaruhi oleh faktor lain.

Penelitian ini sejalan dengan teori yang dikemukakan oleh Herminanto bahwa faktor yang mempengaruhi kesiapan memasuki dunia kerja diantaranya yaitu pengalaman praktik luar, dan prestasi belajar sebelum bekerja (Herminanto, 1992). Dalam hal ini dapat diartikan pakerin adalah suatu wadah dimana siswa bisa mendapatkan pengalaman praktik di luar pembelajaran sekolah, sedangkan UKK digunakan sebagai tolak ukur prestasi siswa selama belajar di SMK. Kompetensi yang diberikan selama pembelajaran di sekolah sudah distandarkan dalam kurikulum yang berlaku. 


\section{TEKNO Jurnal Teknologi, Elektro, dan Kejuruan}

http://journal2.um.ac.id/index.php/tekno | ISSN 1693-8739

Menurut Hamalik (2001), "Praktik kerja pada hakekatnya adalah suatu program latihan yang diselenggarakan di lapangan atau di luar kelas, dalam rangka kegiatan pembelajaran, sebagai bagian integral program latihan". Berdasakan pernyataan diatas dapat disimpulkan bahwa prakerin merupakan suatu sistem pembelajaran di industri atau instansi yang relevan dengan kompetensi keahlian yang dimiliki siswa selama kurun waktu tertentu. Prakerin memberikan kesempatan kepada siswa untuk mengasah skill yang telah dimiliki. Dengan demikian siswa memiliki bekal yang cukup dan akan lebih siap untuk terjun dalam dunia industri dan dunia usaha.

Terbuktinya hipotesis ketiga ini dapat memberikan informasi bahwa kompetensi keahlian dan kesesuaian prakerin memiliki hubungan yang positif dan signifikan terhadap kesiapan memasuki kerja. Oleh sebab itu kompetensi keahlian dan kesesuaian praktik kerja industri sudah selayaknya diperhtikan dalam meningkatkan kesiapan memasuki dunia kerja. Semakin baik kompetensi keahlian dan semakin tinggi kesesuaian prakerin maka semakin tinggi pula kesiapan siswa dalam memasuki dunia kerja

\section{Kesimpulan dan Saran}

\section{A. Kesimpulan}

Bedasarkan hasil penelitian yang telah dilakukan dapat diperoleh kesimpulan diantaranya yaitu:

1. a) Dari hasil analisis deskripsi diketahui bahwa tingkat kompetensi keahlian pada siswa kelas XII progam keahlian Teknik Listrik di SMK Kabupaten Sidoarjo masuk dalam kategori tinggi yaitu sebesar $74 \%$.

b) Dari hasil analisis deskripsi dapat diketahui bahwa tingkat kesesuaian prakerin pada siswa kelas XII progam keahlian Teknik Listrik di SMK Kabupaten Sidoarjo masuk dalam kategori sesuai yaitu sebesar $43 \%$.

c) Dari hasil analisis deskripsi dapat diketahui bahwa tingkat kesiapan memasuki dunia kerja pada siswa kelas XII progam keahlian Teknik Listrik di SMK Kabupaten Sidoarjo masuk dalam kategori tinggi yaitu sebesar $43 \%$.

2. Terjadi hubungan yang signifikan antara kompetensi keahlian dengan kesiapan memasuki dunia kerja pada siswa kelas XII progam kahlian Teknik Listrik di SMK Kabupaten Sidoarjo.

3. Terjadi hubungan yang signifikan antara kesesuaian praktik kerja industri dengan kesiapan memasuki dunia kerja pada siswa kelas XII progam kahlian Teknik Listrik di SMK Kabupaten Sidoarjo.

Terjadi hubungan yang positif dan signifikan antara kompetensi keahlian dan kesesuaian praktik kerja industri secara bersama-sama terhadap kesiapan memasuki dunia kerja pada siswa kelas XII progam kahlian Teknik Listrik di SMK Kabupaten Sidoarjo. 


\section{TEKNO Jurnal Teknologi, Elektro, dan Kejuruan}

http://journal2.um.ac.id/index.php/tekno | ISSN 1693-8739

\section{B. Saran}

Dari kesimpulan yang telah dijabarkan, maka dapat diajukan beberapa saran diantaranya yaitu:

1. Diharapkan kepala sekolah beserta guru tetap memberika pembelajaran yang mendukung kompetensi keahlian dan memberikan praktik-praktik yang dapat mengasah kemampuan siswa lebih baik lagi. Memberikan praktikum yang relevan dengan kebutuhan dunia industry saat ini. Agar menjadi lulusan yang poduktif dan dapat diterima di dunia industri maupun dunia usaha.

2. Diharapkan kepada bagian kuikulum dapat menyusun program prakerin yang tepat dan sesuai dengan kompetensi keahlian yang dimiliki siswa. Serta perlunya memperluas dan menetapkan kerjasama dengan instansi industri yang relevan agar proses pembelajaran sistem ganda dapat berjalan dengan lancar dan optimal.

3. Diharapkan kepada industri dan instansi terkait dengan program keahlian Teknik Listrik dapat menjalin kerjasama secara terbuka dengan SMK. Dengan demikian akan memberikan kontribusi yang baik dalam mencetak lulusan SMK yang siap dalam bekerja.

4. Penelitian ini membahas tentang kesiapan memasuki dunia kerja yang melibatkan dua variabel bebas yaitu kompetensi keahlian dan kesesuaian praktik kerja industri. Bagi peneliti selanjutya hendaknya memperhatikan variabel lain yang dapat mempengaruhi kesiapan memasuki dunia kerja, karena kompetensi keahlian dan kesesuaian praktik kerja industri hanya berpengaruh 74,85\%. Beberapa variabel yang dapat mempengaruhi kesiapan memasuki dunia kerja yaitu wawasan dunia kerja, bimbingan karier, prestasi belajar, dan sebagainya.

\section{Daftar Rujukan}

Arikunto, Suharsimi. 2014. Prosedur Penelitian : Suatu Pendekatan Praktik. Jakarta : Rineka Cipta.

Departemen Pendidikan dan Kebubudayaan. 1994. Konsep Sistem Ganda pada Pendidikan Menengah Kejuruan di Indonesia. Jakarta: Departemen Pendidikan dan Kebubudayaan

Ghozali, Imam. 2011. Aplikasi Analisis Multivaiate Dengan Pogram SPSS.Semarang: BP.UNDIP.

Hamalik, Oemar. 2001. Pendidikan Tenaga Kerja Nasional Kejuruan, Kewirausahaan Dan Manajemen. Bandung: Citra Aditya Bakti

Herminanto, Sofyan. 1992. Kesiapan Kerja Siswa STM di Jawa. Laporan Penelitian. Yogyakarta: IKIP Yogyakarta. 


\section{TEKNO Jurnal Teknologi, Elektro, dan Kejuruan}

http://journal2.um.ac.id/index.php/tekno | ISSN 1693-8739

Miswanto, Bambang. 2007. Studi Tentang Hambatan-Hambatan Pelaksanaan Pendidikan Sistm Ganda (PSG) Model Block Release (Studi Kasus pada Program Program Studi Mekanik Otomotif SMK Negeri 1 Udanawu Blitar). Skripsi tidak diterbitkan. Malang: Teknik Mesin UM

Mangkunegara, Prabu. 2003. Perencanaan dan Pengembangan Sumber Daya Manusia. Bandung: Refika Aditama.

Mulyasa, E. 2006. Kurikulum Berbasis Kompetensi: Konsep, Karakteristik dan Implementasi. Bandung: PT Remaja Rosdakarya.

Oktavia, M. dkk. 2014. Kontribusi Pengalaman Prakerin dan Kompetensi Kejuruan terhadap Kesiapan Memasuki Dunia Kerja Industri Siswa Program Teknik Komputer dan Jaringan Kelas XII di SMK N 2 Padang Panjang. Jurnal Vokasional Teknik Elektronika dan Informatika, (online), 2 (1): 15, (http://ejournal.unp.ac.id), diakses 12 Oktober 2016.

Priyatno, Duwi. 2012. Cara Kilat Belajar Analisis dengan SPSS 20. Jogjakarta: C.V Andi OFFSET.

Putriatama, Ega, dkk. 2016. Kontribusi Pengalaman Prakerin, Wawasan Dunia Kerja dan Kompetensi Kejuruan Melalui Employability Skill Serta Dampaknya Terhadap Kesiapan Kerja Lulusan SMK Kompetetensi Keahlian Teknik Komputer dan Jaringan di Probolinggo. (online), (http://journal.um.ac.id). Diakses 12 oktober 2016.

Slameto. 2010. Belajar dan Faktor- faktor yang Mempengaruhinya. Jakarta: Rineka Cipta.

Sugiyono. 2013. Metode Penelitian Kuantitatif, Kualitatif dan R\&D. Bandung: Alfabeta.

Sukmadinata, Nana Syaodih. 2013. Metode Penelitian Pendidikan. Bandung: PT Remaja Rosdakarya

Undang-undang RI No. 20 Tahun 2003 tentang Sistem Pendidikan Nasional. (Online), (http/riau.kmenag.go.id), diakses 10 Oktober 2016.

Wena Made. 1997. Pendidikan Kejuruan Sistem Ganda. Malang Depdikbud IKIP Malang Bagian Poyek Operasi dan Perawatan Fasilitas Proyek IKIP Malang.

Wohlin, Claes dan Bjorn Regnell. 1999. Strategies for Industrial Relevance in Software Enginering Education. Journal of System and Software, 49(2):125-134. 